\title{
Louise Wells
}

The Greek language of healing from

Homer to New Testament times

$W$
DE
$G$ 


\title{
Beihefte zur Zeitschrift für die neutestamentliche Wissenschaft und die Kunde der älteren Kirche
}

\author{
Herausgegeben von \\ Erich Gräßer
}

Band 83

Walter de Gruyter - Berlin · New York

1998 


\author{
Louise Wells
}

\title{
The Greek language of healing from Homer to New Testament times
}

Walter de Gruyter · Berlin · New York 1998 
(20) Printed on acid-free which falls within the guidelines of the ANSI to ensure permanence and durability.

Die Deutscbe Bibliothek - Cataloging-in-Publication Data

[Zeitschrift für die neutestamentliche Wissenschaft und die Kunde der älteren Kirche / Beihefte]

Beihefte zur Zeitschrift für die neutestamentliche Wissenschaft und die Kunde der älteren Kirche. - Berlin ; New York : de Gruyter

Früher Schriftenreihe

Reihe Beihefte zu: Zeitschrift für die neutestamentliche Wissenschaft und die Kunde der älteren Kirche

Bd. 83. Wells, Louise: The Greek language of healing from Homer to New Testament times. - 1998

Wells, Louise:

The Greek language of healing from Homer to New Testament times / Louise Wells. - Berlin ; New York : de Gruyter, 1998

(Beihefte zur Zeitschnft für die neutestamentliche Wissenschaft und die Kunde der älteren Kirche ; Bd. 83)

Zugh.: Diss., 1993

ISBN 3-11-015389-0

\section{ISSN 0171-6441}

(C) Copyright 1998 by Walter de Gruyter GmbH \& Co., D-10785 Berlin

All rights reserved, including those of translation into foreign languages. No part of this book may be reproduced or transmitted in any form or by any means, electronic or mechanical, including photocopy, recording or any information storage and retrieval system, without permission in writing from the publisher.

$$
\text { Printed in Germany }
$$

Printing: Werner Hildebrand, Berlin

Binding: Lüderitz \& Bauer-GmbH, Berlin 
For my family 
